\title{
Teachers' Beliefs About Literacy Teaching in Japanese Elementary Schools from the Perspective of Special Needs Education
}

\begin{abstract}
Chie MiyaderA*
Faculty of Education, Chiba University, Japan

Teachers' beliefs influence their practices. Furthermore, their pedagogical beliefs play a crucial role in shaping their teaching practices. Furthermore, teachers' beliefs have a significant effect on students' learning, especially literacy learning. Accordingly, in this study, teachers' beliefs about literacy teaching for elementary school students were examined from the perspective of special needs education. The purpose of the study was to develop the Literacy Belief Scale to measure Japanese elementary school teachers' beliefs about literacy instruction in general education classes. The participants, who included 179 Japanese elementary school teachers with a range of teaching experience across both general and special education classes, completed a questionnaire. Factor analysis was performed and three belief dimensions regarding literacy in general education classes were extracted. The results revealed that teachers' beliefs toward pedagogical approaches are dependent on individual practice and experience.
\end{abstract}

Key Words: teachers' beliefs, literacy instruction, students with disabilities, special needs education, Japanese elementary education

\section{Introduction}

Shavelson and Stern (1981) stated that teachers' behavior is guided by their thoughts, judgments, and decisions. Moreover, their attitudes, which are guided by their beliefs, are associated with students' motivation to learn (Deci, Nezlek, \& Sheinman, 1981). Richardson (1996) noted that these attitudes and beliefs are essential concepts in understanding teachers' thought processes, classroom practices, teacher change processes, and how they learn to teach. Accordingly, it is imperative to examine teachers' beliefs about their roles and how best to perform them. It is apparent that teachers' attitudes affect students' motivation in the classroom and their beliefs are directly related to students' education.

Discussions about the education of children with

\footnotetext{
* Corresponding Author

Mailing Address: 1-33 Yayoicho, Chiba-shi, Chiba 263-8522, Japan

E-mail Address: miyadera@faculty.chiba-u.jp

Received August 3, 2020, Accepted June 26, 2021

DOI: $10.6033 /$ specialeducation.10.1
}

special educational needs in regular classrooms have been prevalent since the 1994 UNESCO Salamanca Statement defined inclusive education. A teacher's attitude is one of several essential elements for promoting inclusive education. Saloviita (2018) asserted that teachers' positive attitudes are crucial for educational success and revealed that special education teachers scored higher than regular classroom and subject teachers in a survey on attitudes toward inclusion in basic schools, that is, those who educate students between 7 and 15 years of age. Avramidis, Bayliss, and Burden (2000) found that teachers with substantial training in special education tend to have significantly high positive attitudes toward inclusion. Furthermore, Schmidt and Vrhovnik (2015) demonstrated that teachers without special needs training did not agree as much about providing support and assistance for students with special needs as did those with training. Similarly, Avramidis and Kalyva (2007) found that general education teachers in elementary schools, who had been actively involved in teaching pupils with special education needs, had significantly more positive attitudes than teachers with little or no special needs education experience, thus emphasiz- 
ing the importance of long-term teacher training to develop positive attitudes toward inclusion.

Teachers' pedagogical values shape their literacy teaching practices fundamentally in elementary schools. The Writing Orientation Scale was developed to measure elementary teachers' theoretical orientations about writing instruction (Graham, Harris, MacArthur, \& Fink, 2002). The scale measures teachers' beliefs across three areas: correctness in writing, explicit instruction, and natural learning methods. Results have revealed that most teachers related their theoretical stances to classroom writing practices (Graham et al., 2002). Moreover, most teachers valued direct instruction and informal learning methods rather than emphasizing correctness in writing. Bingham and Hall-Kenyon (2013) examined teachers' beliefs about literacy in the United States so as to explore their views about the centrality of children's literacy skills and implementation of literacy practices. The participants were first asked about their beliefs about literacy skills and literacy instructional strategies with regard to reading success. Second, Bingham and Hall-Kenyon (2013) focused on balanced literacy that combines skill- and meaningbased instruction in literacy education. By employing the Theoretical Orientation in Reading Instruction scale (DeFord, 1985) to assess beliefs about effective reading instruction, they found that teachers believed that reading instruction should reflect a balanced literacy mindset. One may deduce that teachers' pedagogical methods, along with their beliefs, are essential factors in education.

In Japan, studies have explored Japanese language teachers' beliefs about second language acquisition (Nishino, 2012; Yamada, 2014) and elementary school teachers' irrational beliefs (Kawamura \& Kokubun, 1996; Miyaki, 2011). Second and foreign language teachers' beliefs have a considerable influence on their classroom practices (Pajares, 1992). Nishino (2012) revealed that teachers' learning experiences, in-service training, and contextual factors are related to their beliefs and practices. Commonality is evident in second and foreign language teachers' beliefs because they are language teachers. Research has also been conducted on elementary school teachers' irrational beliefs. In Japanese elementary schools, one teacher usually plans and teaches almost every subject in regular classes. Because there is only one teacher per class, elementary school teachers believe that they must do everything, which exacerbates their stress. Moreover, studies have revealed that teachers in classes that comprise many children tend to be inattentive and are more likely to experience stress, thus internalizing irrational beliefs (Miyaki, 2011).

Since 2012, the promotion of special education has formed part of the endeavor to develop an inclusive education system, with the ultimate goal of fostering a symbiotic society in Japan. A survey conducted by the Ministry of Education, Culture, Sports, Science and Technology (2012) revealed that students with special needs as well as developmental, social, and/ or attention disorders or other disabilities in regular elementary (children aged 6-12) and junior high schools (children aged 13-15) accounted for approximately $6.5 \%$ of all students. This survey further revealed that, based on learning disabilities criteria, approximately $4.5 \%$ of all students experienced difficulties with reading and writing in general education classes, battled to read sentences written in hiragana, which is a Japanese writing system component, and often read slowly and sporadically. Many also battled to write letters (mainly kanji) correctly. Because students may experience difficulties in general education, it is imperative to develop strategies that support literacy learning in regular classes.

With regard to beneficial literacy learning methods, in the United States and England, teachers often conduct phonics-focused reading (e.g., Wyse \& Goswami, 2008), especially for young English learners. In Japan, children start writing letters (hiragana and katakana) in the first grade (children aged 6-7). These letters are easy to learn as there is a one-toone correspondence between letters and sounds. However, because kanji have multiple readings and their shapes are complicated, children often struggle to learn kanji.

Recently, teachers in Japan have improved their abilities and increased their willingness to apply their pedagogical approaches to students' individual educational needs. Methods related to reading and writing instructions have changed considerably since an increased focus on students with learning disabilities has become prevalent. Haruhara, Uno, and Kaneko (2005) argued that writing kanji repeatedly has little efficacy for students with learning disabilities. Suzuki and Inagaki (2018) examined a kanji training program for a boy with a developmental coordination disorder in which kanji was taught by dividing letters 
into known parts and he was required to verbalize the parts. They proposed that kanji teaching methods be tailored to children's specific abilities. However, the primary issue involves the most optimal way to incorporate these teaching methods in regular classes.

Teachers' attitudes toward inclusion have also been examined in Japan. The results of an exploration of teachers' comprehension of special education in elementary and junior high school found that when teachers had significant special education experience, it had a positive influence on their understanding of and ability to provide special needs education as well as in their interest in special needs education and the needs of the teaching staff to learn (Kojima, Yoshitoshi, Ishibashi, Hiraga, Kataoka, Korenaga, Maruyama, \& Mizuuchi, 2011). To date, however, despite the importance of literacy learning in elementary school education, teachers' attitudes toward reading and writing specifically have not been explored. Therefore, it is imperative that teachers' views on literacy learning related to special education should be examined. Guskey (2002) proposed the Model of Teacher Change, which posits that attitudes and beliefs about teaching are derived chiefly from teachers' classroom experience, that is, teachers' experiences shape their attitudes and beliefs. Thus, positive changes in teachers' attitudes and beliefs toward special education are likely to lead to an improvement in students' learning outcomes. In relation to changing teachers' attitudes, Avramidis et al. (2000) revealed that educating students with disabilities in regular classrooms leads to positive changes in educators' attitudes. Studies have shown that elementary school teachers tend to have various robust and unfounded beliefs about teaching (Kawamura \& Kokubun, 1996). To the best of our knowledge, no studies in Japan have examined teachers' beliefs about literacy instruction in relation to special education. Therefore, it is imperative to explore teaching methods that support children in general classes, regardless of whether they have learning disabilities or not, and to ascertain the most appropriate teaching forms in relation to special needs education. Therefore, it is crucial to study teachers' beliefs in relation to the recent promotion of special education in Japan.

The following two research questions were addressed:
1) What beliefs do teachers in Japanese elementary schools have about literacy teaching in general education classes?

2) From the perspective of special needs education, what beliefs do teachers possess and how do their experiences affect their beliefs?

Accordingly, teachers' beliefs about literacy teaching in general education classes in Japanese elementary schools were examined so as to shed light on their characteristics from the perspective of special needs education. The Literacy Belief Scale was developed to assess elementary teachers' beliefs about teaching literacy and enhancements for students with disabilities in general education through an analytical understanding of teachers' present beliefs. In addition, the teachers' experiences in both general and special education were compared and their different experiences were explored to determine their effect on their beliefs. The Model of Teacher Change (Guskey, 2002) posits that teachers require practical experience to change their beliefs and, in turn, changes in students' learning outcomes can change teachers' beliefs. In this study, it was understood that it was necessary for teachers to have several years of teaching experience to have developed, changed, and/ or established beliefs about their teaching methods.

We designed a questionnaire to evaluate reading and writing teaching methods so as to shed light on teachers' beliefs and develop the Literacy Belief Scale. We first hypothesized that teachers' beliefs can be divided into reading and writing skills and second, that the more experience teachers have, the stronger their pedagogical beliefs about literacy are. Because teachers' beliefs change through experiences (Yamada, 2014) or in-service training (Nishino, 2012), more experienced teachers may possess various beliefs related to teaching methods. Finally, with regard to special education teaching, we proposed that teachers' beliefs vary in relation to the length of time they have been teaching special education. Studies (Avramidis et al., 2000; Schmidt \& Vrhovnik, 2015) have found that teachers who have taught children with special needs tend to have positive attitudes toward inclusion.

\section{Method}

\section{Participants}

The participants included 179 elementary school 
Table 1 Participant Demographics (Gender, Type of Class, Teaching Experience, and Special Education Teaching Experience)

$(N=179)$

\begin{tabular}{|c|c|c|c|}
\hline Background Variables & Groups & $N$ & $\%$ of the Sample \\
\hline \multirow[t]{2}{*}{ Gender } & Male & 74 & 41.34 \\
\hline & Female & 105 & 58.66 \\
\hline \multirow[t]{10}{*}{ Type of Class } & Class teacher & 149 & 83.24 \\
\hline & General education class & 140 & 78.21 \\
\hline & Grade 1 & 26 & 14.53 \\
\hline & Grade 2 & 25 & 13.97 \\
\hline & Grade 3 & 22 & 12.29 \\
\hline & Grade 4 & 21 & 11.73 \\
\hline & Grade 5 & 25 & 13.97 \\
\hline & Grade 6 & 21 & 11.73 \\
\hline & Special education class & 9 & 5.03 \\
\hline & Administrative/special course & 30 & 11.17 \\
\hline \multirow[t]{6}{*}{ Teaching Experience } & Less than 5 years & 46 & 25.70 \\
\hline & $6-10$ years & 43 & 24.02 \\
\hline & $11-20$ years & 43 & 24.02 \\
\hline & $21-30$ years & 18 & 10.06 \\
\hline & Over 31 years & 28 & 15.64 \\
\hline & Missing & 1 & 0.56 \\
\hline \multirow[t]{8}{*}{ Special Education Teaching Experience } & None & 142 & 79.33 \\
\hline & Some & 35 & 19.55 \\
\hline & Less than 5 years & 25 & 13.97 \\
\hline & $6-10$ years & 4 & 2.23 \\
\hline & $11-20$ years & 3 & 1.68 \\
\hline & $21-30$ years & 1 & 0.56 \\
\hline & Over 31 years & 2 & 1.12 \\
\hline & Missing & 2 & 1.12 \\
\hline
\end{tabular}

teachers from one Japanese city who were or had been in charge of general elementary education classes in public schools. A summary of their demographic information is presented in Table 1 . Of the 228 questionnaires we distributed among teachers, 179 in 16 schools (78.5\% response rate) returned completed questionnaires.

\section{Survey Instrument}

The questionnaire comprised demographic questions related to gender, class, teaching experience, and special education teaching experience. Two questionnaire types were employed to design the questionnaire. First, items based on Graham et al's (2002) writing orientation questionnaire and Troia and Graham's (2017) teachers' efficacy questionnaire were drafted. Thereafter, tentative questionnaire items related to the current state of Japanese language education in Japan were drafted in accordance with the Elementary School Teaching Guide for the Japanese Course of Study: Japanese Language. The latter is the standard curriculum of school education, which the Minister of Education, Culture, Sports, Science, and Technology implemented in 2019. Each school is expected to employ these guidelines to provide education. Subsequently, a teacher with over 15 years of experience teaching general and special education classes in elementary schools advised us on teaching methods often used in general education classes and special education classes, assessed the appropriateness of the questionnaire items for elementary school teachers, and amended those that were not appro- 
priate. After developing 20 questions, a teacher with over 30 years of experience in mainstream elementary and special education school teaching examined them in detail. Two elementary school principals then completed the survey and highlighted items that were difficult to answer. Finally, we employed a questionnaire with 18 items that were evaluated on a fourpoint Likert scale, ranging from 1 (strongly disagree) to 4 (strongly agree) to measure teachers' beliefs about inclusion and support for students with learning disabilities.

\section{Procedures}

Data were collected from October 2018 to February 2019. After a request had been sent to school principals, questionnaires were distributed to those schools that provided consent. Every teacher was free to participate. The completed questionnaires were either returned personally or mailed.

Ethical procedures were followed. First, the participants were not requested to provide identifying information. Second, none of the questions were mandatory and the participants were assured they would not be penalized for submitting an incomplete questionnaire. Third, the participants were informed that the data would only be processed statistically. By answering the questionnaire, the participants provided consent. The study was approved by the ethics committee at Chiba University (approval number: 111).

The ceiling effect and skewness were confirmed after calculating the mean and standard deviation. Furthermore, factor analysis, specifically, varimax rotation was performed several times to confirm the factor loading and commonality.

\section{Results}

\section{Factor Analysis}

The mean and standard deviation of the 18 items are displayed in Table 2 . To determine the underlying factor structure of the Literacy Belief Scale, explor-

Table 2 Mean $(M)$ and Standard Deviation $(S D)$ for Questionnaire Items

\begin{tabular}{|c|c|c|c|}
\hline & Items & M & $S D$ \\
\hline 1 & Teachers must develop the language skills necessary for everyday life in every child. & 3.14 & 0.72 \\
\hline 2 & Students who cannot learn kanji in a regular class need to be individually instructed. & 3.21 & 0.75 \\
\hline 3 & Students who are not good at reading aloud may have developmental disabilities, so specialised examination is required. & 2.43 & 0.79 \\
\hline 4 & $\begin{array}{l}\text { We strive every day to ensure that all students in our class reach the same academic ability, whether or not they have } \\
\text { developmental disabilities. }\end{array}$ & 2.89 & 0.84 \\
\hline 5 & $\begin{array}{l}\text { Even if some children have not learned the content in their previous grades, I cannot afford the number of hours } \\
\text { required to help them catch up, so I have to teach them the content for the current grade. }\end{array}$ & 2.42 & 0.96 \\
\hline 6 & Besides learning at school, home learning is essential. & 3.61 & 0.59 \\
\hline 7 & It is important to learn the basics of reading and writing at the elementary school level. & 3.70 & 0.53 \\
\hline 8 & $\begin{array}{l}\text { To write kanji correctly, it is essential to teach students using the learning method that best suits them rather than by } \\
\text { repetitive practice only. }\end{array}$ & 3.38 & 0.65 \\
\hline 9 & $\begin{array}{l}\text { Essay-writing should emphasize expressing your feelings and what you want to write in your own way, rather than } \\
\text { writing correctly. }\end{array}$ & 2.91 & 0.71 \\
\hline 10 & By repeating the practice of reading and writing, students will naturally learn how to read and write correctly. & 2.62 & 0.78 \\
\hline 11 & $\begin{array}{l}\text { In learning to write letters and sentences, even if students make mistakes in the text they write in their own words, } \\
\text { teachers should respect their feelings by not correcting them. }\end{array}$ & 1.66 & 0.70 \\
\hline 12 & Diary and free compositions should be written freely by students regardless of sentence structure. & 2.40 & 0.79 \\
\hline 13 & $\begin{array}{l}\text { For students who have difficulty reading aloud, it is essential to read the correct sentence repeatedly to help them } \\
\text { learn by listening. }\end{array}$ & 2.70 & 0.76 \\
\hline 14 & It is necessary to practice writing over and over again to acquire kanji. & 3.03 & 0.82 \\
\hline 15 & Learning idioms is useful for learning letters. & 2.80 & 0.74 \\
\hline 16 & $\begin{array}{l}\text { Learning to read and write kanji in elementary school is vital in determining the most suitable occupations for } \\
\text { students in the future. }\end{array}$ & 3.27 & 0.72 \\
\hline 17 & It is essential for students to learn the correct stroke order. & 2.85 & 0.75 \\
\hline 18 & For students who are not good at reading, it is crucial to read content from textbooks that most interest the student. & 3.21 & 0.60 \\
\hline
\end{tabular}


Table 3 Items and Factor Loadings for the Literacy Belief Scale

\begin{tabular}{|c|c|c|c|c|}
\hline \multirow{2}{*}{ Items } & \multicolumn{3}{|c|}{ Factor Loadings } & \multirow{2}{*}{$\begin{array}{c}\text { Coefficien } \\
\quad \alpha\end{array}$} \\
\hline & I & II & III & \\
\hline \multicolumn{5}{|l|}{ I. Teachers' beliefs about letters and words teaching methods for literacy learning } \\
\hline 14. It is necessary to practice writing over and over again to acquire kanji. & 0.77 & -0.18 & -0.11 & 0.71 \\
\hline 17. It is essential for students to learn the correct stroke order. & 0.56 & -0.06 & 0.16 & \\
\hline $\begin{array}{l}\text { 16. Learning to read and write kanji in elementary school is vital in determining the most suitable } \\
\text { occupations for students in the future. }\end{array}$ & 0.56 & 0.03 & 0.08 & \\
\hline 15. Learning idioms are useful for learning letters. & 0.56 & 0.17 & 0.09 & \\
\hline $\begin{array}{l}\text { 10. By repeating the practice of reading and writing, students will naturally learn how to read and } \\
\text { write correctly. }\end{array}$ & 0.44 & 0.05 & 0.10 & \\
\hline \multicolumn{5}{|l|}{ II. Teachers' beliefs about sentence teaching methods for literacy learning } \\
\hline $\begin{array}{l}\text { 12. Diary and free compositions should be written freely by students regardless of sentence } \\
\text { structure. }\end{array}$ & 0.05 & 0.53 & -0.02 & 0.52 \\
\hline $\begin{array}{l}\text { 11. In learning to write letters and sentences, even if students make mistakes in the text they write } \\
\text { in their own words, teachers should respect their feelings by not correcting them. }\end{array}$ & -0.07 & 0.46 & 0.10 & \\
\hline $\begin{array}{l}\text { 13. For students who have difficulty reading aloud, it is essential to read the correct sentence } \\
\text { repeatedly to help them learn by listening. }\end{array}$ & 0.41 & 0.46 & 0.07 & \\
\hline $\begin{array}{l}\text { 9. Essay-writing should emphasise expressing your feelings and what you want to write in your } \\
\text { own way, rather than writing correctly. }\end{array}$ & -0.12 & 0.38 & 0.25 & \\
\hline \multicolumn{5}{|l|}{ III. Teachers' beliefs about teaching for literacy learning in general education classes } \\
\hline 1. Teachers must develop the language skills necessary for everyday life in every child. & 0.05 & 0.09 & 0.67 & 0.52 \\
\hline 2. Students who cannot learn kanji in regular class need to be individually instructed. & 0.13 & 0.05 & 0.52 & \\
\hline $\begin{array}{l}\text { 3. Students who are not good at reading aloud may have developmental disabilities, so } \\
\text { specialised examination is required. }\end{array}$ & 0.01 & 0.29 & 0.37 & \\
\hline
\end{tabular}

atory factor analysis was applied to the participants' responses. Initially, three items, namely, 6,7 , and 8 were excluded because of ceiling effects.

Factor analysis, specifically, varimax rotation was subsequently performed on 15 items. Based on the eigenvalues, cumulative contribution rate, factor loadings (Table 3 ), and interpretability of factors, three factors $(0.35$ or more) were extracted. A further three items, namely, 4, 5, and 18 were deleted, thus reducing the items to 12 . Two of the factors were relevant for measuring teachers' beliefs about teaching literacy learning: Teachers' beliefs about letters and words teaching methods for literacy learning (Factor I) and Teachers' beliefs about sentence teaching methods for literacy learning (Factor II). While the former emphasizes letter and word learning practices that are similar to the repetitive writing of kanji characters with a focus on stroke order and teaching methods that use idioms, the latter focuses on reading sentences and writing teaching methods that guide students. Factor III, which was Teachers' beliefs about teaching for literacy learning in general education classes, focused on teachers' beliefs and attitudes about teaching literacy to general students. In particular, they expressed teachers' beliefs and practices with regard to students with special needs in regular classes.

We calculated Cronbach's coefficient alpha to confirm the reliability of the data. The results revealed the alpha values were $0.705,0.52$, and 0.517 for Factors I, II, and III, respectively. If the coefficient alpha exceeded 0.5 , internal consistency was guaranteed.

\section{Teachers' Scores}

The mean and $S D$ for Factors I, II, and III were $2.918 \quad(S D=0.52), \quad 2.418 \quad(S D=0.47), \quad$ and 2.925 $(S D=0.54)$, respectively.

\section{Differences According to Teaching Experience}

The teachers were divided into five groups related 
Table 4 Mean $(M)$, Standard Deviation $(S D)$, and F-scores According to Teaching Experience for Each Factor

\begin{tabular}{|c|c|c|c|c|c|c|c|c|}
\hline \multirow[b]{2}{*}{ Literacy Belief Scale } & \multicolumn{5}{|c|}{ Teaching Experience } & \multirow[b]{2}{*}{$F$-score } & \multirow[b]{2}{*}{$p$} & \multirow[b]{2}{*}{ Tukey } \\
\hline & $\begin{array}{l}\text { Less than } \\
5 \text { years }\end{array}$ & $\begin{array}{l}6-10 \\
\text { years }\end{array}$ & $\begin{array}{l}11-20 \\
\text { years }\end{array}$ & $\begin{array}{l}21-30 \\
\text { years }\end{array}$ & $\begin{array}{l}\text { Over } 31 \\
\text { years }\end{array}$ & & & \\
\hline \multirow{2}{*}{$\begin{array}{l}\text { I. Teachers' beliefs about letters and words } \\
\text { teaching methods for literacy learning }\end{array}$} & 3.12 & 2.93 & 2.75 & 2.78 & 2.88 & \multirow[t]{2}{*}{3.58} & \multirow[t]{2}{*}{$* *$} & $11-20$ years \\
\hline & -0.50 & -0.40 & -0.54 & -0.53 & -0.53 & & & $<$ Less than 5 years \\
\hline \multirow{2}{*}{$\begin{array}{l}\text { II. Teachers' beliefs about sentence teaching } \\
\text { methods for literacy learning }\end{array}$} & 2.35 & 2.40 & 2.36 & 2.54 & 2.55 & \multirow[t]{2}{*}{1.28} & & \\
\hline & -0.44 & -0.52 & -0.45 & -0.49 & -0.45 & & & \\
\hline \multirow{2}{*}{$\begin{array}{l}\text { III. Teachers' beliefs about teaching for literacy } \\
\text { learning in general education classes }\end{array}$} & 2.83 & 2.92 & 2.81 & 2.96 & 3.18 & \multirow[t]{2}{*}{2.46} & \multirow[t]{2}{*}{$*$} & $11-20$ years \\
\hline & -0.48 & -0.48 & -0.52 & -0.67 & -0.52 & & & $<$ Over 31 years \\
\hline
\end{tabular}

$* * p<.01,{ }^{*} p<.05$

to their teaching experience: less than 5 years, 6-10 years, 11-20 years, 21-30 years, and over 31 years. Analysis of variance (ANOVA) was performed on their responses and differences between teaching experiences were examined. The results of the ANOVA revealed that the scores for Factors I and III differed significantly in relation to teaching experience (Table 4). While the scores of the group with less than 5 years of experience were significantly higher than those of teachers with 11-20 years of experience for Factor I $(p<.01)$, the scores of the 11-20 years group were significantly lower than those of the over 31 years group $(p<.05)$ for Factor III.

\section{Differences According to Special Education Teaching Experience}

The average scores of the participants with no experience in special education $(n=142)$ and those with at least 1 year of experience $(n=35)$ were compared for each factor. For Factor I, the scores of the groups with and without special education experience were $2.840(S D=0.55)$ and $2.936(S D=0.50)$, respectively. The scores of the groups with and without experience were $2.436(S D=0.52)$ and 2.412 $(S D=0.46)$, respectively for Factor II. Finally, for Factor III, the scores of the groups with and without experience were $2.981 \quad(S D=0.56)$ and 2.907 ( $S D=0.53)$, respectively. $t$-tests showed no significant differences between the groups' mean scores with regard to each factor ( $t$-scores: $0.996,-0.267$, and -0.730 , respectively).

\section{Discussion}

Teachers' beliefs exert a powerful influence on classroom practices (Pajares, 1992; Shavelson \& Stern, 1981). Furthermore, their literacy practices are shaped by their literacy instruction beliefs (DeFord, 1985). Thus, an understanding of teachers' pedagogical beliefs is imperative to develop future educational practices. Despite this implication, only a paucity of research has been conducted on teachers' beliefs about literacy instruction in elementary schools in Japan.

\section{Teachers' Beliefs About Literacy Teaching in General Classes in Japanese Elementary Schools}

In this study, the Literacy Belief Scale was developed and applied so as to explore elementary school teachers' beliefs about literacy learning from the perspective of special needs education. The purpose of the study was to examine beliefs about teaching methods for literacy learning in regular classes. Three factors or dimensions, which can be employed to measure teachers' beliefs, emerged: Teachers' beliefs about letters and words teaching for literacy learning, Teachers' beliefs about sentence teaching methods for literacy learning, and Teachers' beliefs about teaching for literacy learning in general education classes. The scale examined pedagogical thoughts about supporting children in regular classes and delineated two pedagogical approaches to literacy learning: first, letters and words, which revealed that teachers focus on writing repeatedly by emphasizing stroke order and the importance of students acquiring suitable future occupations, and second, sentences in which teachers emphasize the enjoyment of both writing and reading by not focusing on mistakes but allowing students to write and read freely. The third factor described the need for the individual teaching of students in regu- 
lar classes. This dimension revealed the significance of learning literacy and how to handle students who experience difficulties with reading and writing.

The results revealed that teachers have diverse beliefs about their teaching methods for letters and words as well as sentences in general classes. Most of the teachers appeared to balance the beliefs about both. Our findings partially supported our hypothesis that teachers' pedagogical beliefs are related to teaching experience. Belief in the teaching methods related to letters and words was the highest in teachers who had less than 5 years of experience and lowest in those who had between 11 and 20 years of experience. Notably, belief in the teaching methods used for sentences did not differ significantly across teachers' experience levels and was the lowest-rated factor. The results showed that while belief in the teaching methods for letters and words was dependent on teaching experience, it was dependent on individual practices and expertise for sentences. With regard to teachers' beliefs about teaching in general education classrooms, those with more than 31 years of experience scored the highest. One may deduce that teachers who had a great deal of experience held flexible beliefs. Schmidt and Vrhovnik (2015) found that young teachers between 20 and 30 years of age exhibited more positive attitudes toward the provision of adequate support than other groups. Although the results of this study were not consistent, they suggest that not only knowledge but also field experience is necessary for reading and writing learning instruction. Teachers with over 5 years of experience are increasingly offered opportunities to learn through training tailored to their interests and specialties. Furthermore, many teachers with over 10 years of experience assume important school roles and other teachers often rely on them. Our results revealed there were significant differences between the beliefs of those with more than 11 years of experience and those with less experience. In accordance with Guskey's model (2002), we revealed that when elementary school teachers had more than 10 years of experience in general classes, they became aware that their students' learning outcomes were directly related to their own transformed beliefs. Huberman (1992) proposed a schematic model to explain the successive themes of a teacher's career cycle. After teaching for between approximately 7 and 10 years, while some teachers continue to experiment actively with new practices, others lack the motivation. Teachers with over 31 years of experience had the highest scores regarding beliefs related to literacy learning in regular classes. We found that the majority of teachers with extensive experience, whether they were involved in special needs education or not, taught literacy learning in regular classes from the perspective of special needs. In line with the promotion of special needs education in Japan, our findings suggest that teachers' views about special needs education are largely related to reading and writing learning in regular classes. We demonstrated that although these beliefs are related to years of teaching experience, they are not affected by special education teaching experiences. This does not support our hypotheses and contradicts previous research, which found that teachers with experience in special needs education exhibited a more positive attitude toward inclusion (Avramidis et al., 2000; Avramidis \& Kalyva, 2007; Schmidt \& Vrhovnik, 2015).

\section{Differences in Beliefs Related to Teachers' Experiences in Both General and Special Education}

Kojima et al. (2011) revealed that in comparison to other teachers, those with experience in special education had stronger opinions about its necessity as well as a greater awareness of and interest in it. However, it is unknown how these factors affect each particular aspect of education in regular classes. Our results on the impact of special education experiences differ from those of Kojima et al. (2011). The teachers noted that their belief structures related to special needs education involved many support mechanisms in regular classes, including understanding, skills, interest in special needs education, and parental support. It is possible that the quality of teacher consciousness Kojima et al. (2011) discussed is different from the belief structures that focused on literacy learning in this study. However, the relationship between the scores of beliefs and experiences of special education were not shown in this study. Because beliefs about literacy learning in regular classes were assessed in this study, we are of the opinion that the experience of teaching in special needs schools and classes may not be connected to these beliefs.

We found that teachers with more than 11 years of experience tended to change their beliefs based on feedback of their teaching practices. Moreover, the higher the number of years of experience a teacher 
had, the higher their belief scores for the three factors were. Thus, one may deduce that experienced teachers have high-level beliefs about literacy learning and support that should be provided in regular classes. Therefore, in order to link teachers' beliefs explicitly to their positive teaching practices, it is imperative to establish a system, which provides teachers with more than 11 years of experience with practical support. Our results further indicated the necessity of providing a foundation to support teachers during teacher training toward best practice teaching methods.

\section{Limitations and Recommendations for Future Research}

This study has several limitations. First, we were unable to determine the relationship between teachers' beliefs and their teaching practices. Previous research (Bingham \& Hall-Kenyon, 2013; Deci et al., 1981) has indicated that it is important to examine the relationship between beliefs and practices. Therefore, it is recommended that the relationship between teachers' beliefs and the provision and quality of support for students with learning disabilities in regular schools be explored in future studies. By combining the measurement of teachers' beliefs and practices, ways to support teachers with strategies for literacy learning in regular classes could be highlighted. In addition, it is crucial to examine the influence of training on the formation of teachers' beliefs in literacy learning in regular classes in the Japanese basic education system. A second limitation is related to the nature of the sample. Many of the participants had little experience in teaching students with learning disabilities. Thus, one may deduce there is a need for the development of teacher training and support strategies in Japanese elementary education. It is recommended that teachers with extensive experience in special education constitute the sample when evaluating teachers' beliefs about literacy learning support for students with developmental disabilities. Because learning difficulty labels affect teachers' beliefs (Gibbs \& Elliott, 2015), it is imperative to examine teachers' beliefs related to the frequency and level of teacher engagement with children with special needs as well as the relationship between teachers' beliefs and children's level of special needs. Although teachers' beliefs were examined in this study, it is recommended that teachers' attitudes are also examined in future research.

\section{Acknowledgment}

I am deeply grateful to Ms. Eiko Tsushima and Mr. Harunobu Yasukawa for their many suggestions regarding the preparation of the questionnaire. I am also very grateful to the elementary school teachers for their fruitful advice and participation. This work was supported by JSPS KAKENHI Grant Number 19K02950.

\section{Conflicts of Interest Statement}

The author has no conflicts of interest to declare.

\section{References}

Avramidis, E., Bayliss, P., \& Burden, R. (2000) A survey into mainstream teachers' attitudes towards the inclusion of children with special educational needs in the ordinary school in one local education authority. Educational Psychology, 20, 191-211.

Avramidis, E. \& Kalyva, E. (2007) The influence of teaching experience and professional development on Greek teachers' attitudes towards inclusion. European Journal of Special Needs Education, 22, 367-389.

Bingham, G. E. \& Hall-Kenyon, K. M. (2013) Examining teachers' beliefs about and implementation of a balanced literacy framework. Journal of Research in Reading, 36, 14-28.

Deci, E. L., Nezlek, J., \& Sheinman, L. (1981) Characteristics of the rewarder and intrinsic motivation of the rewardee. Journal of Personality and Social Psychology, 40, 1-10.

DeFord, D. E. (1985) Validating the construct of theoretical orientation in reading instruction. Reading Research Quarterly, 20, 351-367.

Gibbs, S. \& Elliott, J. G. (2015) The differential effects of labelling: How do 'dyslexia' and 'reading difficulties' affect teachers' beliefs. European Journal of Special Needs Education, 30, 323-337.

Graham, S., Harris, K. R., MacArthur, C., \& Fink, B. (2002) Primary grade teachers' theoretical orientations concerning writing instruction: Construct validation and a nationwide survey. Contemporary Educational Psychology, 27, 147-166.

Guskey, T. R. (2002) Professional development and teacher change. Teachers and Teaching, 8, 381-391.

Haruhara, N., Uno, A., \& Kaneko, M. (2005) Training dyslexic boys in writing kanji letters. The Japan Journal of Logopedics and Phoniatrics, 46, 10-15. (in Japanese)

Huberman, M. (1992) Teacher development and instructional mastery. In A. Hargreaves \& M. G. Fullan (Eds.), Understand- 
ing teacher development. Cassell, London, 122-142.

Kawamura, S. \& Kokubun, Y. (1996) A study of teachers' peculiar beliefs in elementary schools. Japanese Journal of Counseling Science, 29, 44-54. (in Japanese)

Kojima, M., Yoshitoshi, M., Ishibashi, Y., Hiraga, K., Kataoka, M., Korenaga, K., Maruyama, K., \& Mizuuchi, T. (2011) Structure of elementary and junior high school teachers' consciousness regarding special education in regular classrooms. Japanese Journal of Special Education, 49, 127-134. (in Japanese)

Ministry of Education, Culture, Sports, Science and Technology (2012) Survey results on students in special classes requiring special educational support with the possibility of developmental disabilities. (in Japanese) https://www.mext.go.jp/a_ menu/shotou/tokubetu/material/1328729.htm (Retrieved March 22, 2021)

Ministry of Education, Culture, Sports, Science and Technology (2019) Elementary school teaching guide for the Japanese course of study: Japanese language. (in Japanese)

Miyaki, H. (2011) Management problems and teachers' stress caused by ADHD children attending regular classes. Japanese Journal of Learning Disabilities, 20, 194-206. (in Japanese)

Nishino, T. (2012) Modeling teacher beliefs and practices in context: A multimethods approach. Modern Language Journal, 96, 380-399.

Pajares, M. F. (1992) Teachers' beliefs and educational research: Cleaning up a messy construct. Review of Educational Research, 62, 307-332.

Richardson, V. (1996) The role of attitudes and beliefs in learn- ing to teach. In J. Sikula (Ed.), Handbook of research on teacher education (Second edition). Macmillan, New York, 102-119.

Saloviita, T. (2018) Attitudes of teachers towards inclusive education in Finland. Scandinavian Journal of Educational Research, $64,270-282$.

Schmidt, M. \& Vrhovnik, K. (2015) Attitudes of teachers towards the inclusion of children with special needs in primary and secondary schools. Hrvatska Revija za Rehabilitacijska Istraživanja, 51, 16-30.

Shavelson, R. J. \& Stern, P. (1981) Research on teachers' pedagogical thoughts, judgments, decisions, and behavior. Review of Educational Research, 51, 455-498.

Suzuki, K. \& Inagaki, M. (2018) Kanji interventions for a child with developmental coordination disorder having difficulties with reading and writing. Japanese Journal of Cognitive Neuroscience, 20, 165-171. (in Japanese)

Troia, G. A. \& Graham, S. (2017) Use and acceptability of writing adaptations for students with disabilities: Survey of grade 3-8 teachers. Learning Disabilities Research \& Practice, 32, $257-269$.

Wyse, D. \& Goswami, U. (2008) Synthetic phonics and the teaching of reading. British Educational Research Journal, 34, 691710 .

Yamada, T. (2014) Changes in Japanese language teachers' beliefs over time: Identifying core beliefs using PAC analysis and semi-structured interviews. Journal of Japanese Language Teaching, 157, 32-46. (in Japanese) 